\title{
Green Degumming of Silk by Enzyme Extracted from Natural Sources
}

\author{
Mahbubur Rahman* ${ }^{\circledR}$, Asim Bhowmik, Sudipta Das, Kartick Chowhan, Tanmoy Biswas \\ Department of Textile Engineering, Mawlana Bhashani Science and Technology University, Tangail, Bangladesh \\ Email: *mahbub.mbstu@gmail.com
}

How to cite this paper: Rahman, M., Bhowmik, A., Das, S., Chowhan, K. and Biswas, T. (2020) Green Degumming of Silk by Enzyme Extracted from Natural Sources. Journal of Materials Science and Chemical Engineering, 8, 30-40. https://doi.org/10.4236/msce.2020.88003

Received: July 13, 2020

Accepted: August 17, 2020

Published: August 20, 2020

Copyright (c) 2020 by author(s) and Scientific Research Publishing Inc. This work is licensed under the Creative Commons Attribution International License (CC BY 4.0).

http://creativecommons.org/licenses/by/4.0/

\section{(c) (i) Open Access}

\begin{abstract}
The main objective of this work is to degum the silk with natural enzyme in lieu of conventional degumming to make it sustainable. Fibroin and sericin are the main composition of silk. Sericin provides a harsh and stiff effect of silk and decreases the valuable property like luster and whiteness and also leads to uneven dyeing. It is necessary to remove this sericin for the better post processing of silk. The removal process of sericin from silk is called degumming. Usually degumming process is done by using chemicals like soda $\left(\mathrm{Na}_{2} \mathrm{CO}_{3}\right)$, detergent and other chemical staffs. But these chemicals are lethal to the environment. So, if such component found that can be substitute the fatal components and give the same required result or very close then that would be considered as an asset. This work deals with the different enzymes extracted from natural sources such as papaya skin, pineapple skin and guava leaf with variation of enzyme concentrations such as 10 (\%), 15 (\%) \& 20 (\%) as well as $35^{\circ} \mathrm{C} 45^{\circ} \mathrm{C} \& 55^{\circ} \mathrm{C}$ temperatures that influence the degumming efficiency. By analyzing the various samples on the basis of degumming efficiency and other tests such as tensile strength, water vapor permeability, pilling and abrasion, crease recovery, whiteness test and spot test are done by standard method, it is found that the enzyme extracted from papaya skin shows the best degumming efficiency $15.9(\%)$ and other tests also show the good result at $15(\%)$ concentration and $45^{\circ} \mathrm{C}$ temperature whereas degumming efficiency 16.6 (\%) for conventional process. From this work, it can be concluded that enzyme extracted from papaya skin can be substituted of conventional degumming which is also ecofriendly.
\end{abstract}

\section{Keywords}

Degumming, Silk, Enzyme, Pineapple Skin, Ecofriendly

\section{Introduction}

Silk is the long natural protein fiber which is produced by a number of different 
insects including silkworms, spiders, scorpions, mites and flies, with each producing a unique variety of silk [1]. The most popular silk type in worldwide is mulberry silk which is produced from Bombyx mori silkworm for its outstanding properties such as softness, strength, dye ability, and luster [2] [3] [4] [5]. Natural silk is a continuous protein-filament spun by the silkworm [6]. The length of fiber in a single cocoon is $600-1500 \mathrm{~m}$ [7]. The silk fiber of the cocoon consists of two protein components namely fibroin and sericin. Fibroin provides the main fibrous structure to the Bombyx mori silkworm while sericin is a glue-like protein that holds the cocoon together [8]-[14]. These sericin or waxes hammer the post processing of silk due to poor wetting property [15]. Removing of sericin from silk is called degumming. Degumming is very important treatment of silk processing because the presence of gum makes the silk harsh, stiff, masks its natural lusture [16] and leads to uneven dyeing. Degumming is the process of cleavage of peptide bonds of sericin either by hydrolytic or enzymatic methods and its subsequent removal from silk [17] [18]. The degumming process removes the sericin layer before dyeing using a solution of soap, synthetic detergents, or proteolytic enzymes [19] [20] [21]. Generally degumming is done by conventional method with soap and alkali but in this work, it is tried to do a different way, where the chemicals were substituted by natural enzymes extracted from papaya skin, pineapple skin and guava leaf to complete green degumming. Enzymes are eco-friendly and work under mild conditions at low temperature, so, consume less energy than any other methods [22]. Green degumming of silk provides a better result and also reduces the load of effluent on environment. Degumming improves the sheen, color, hand, and texture of the silk [23]. Silk fibroin is not only a valuable textile material but also an attractive biomaterial in several medical fields such as tissue engineering, drug delivery, optics, sensing, diagnostics [24]-[30]. Previously [18] [31] [32] [33] worked on the basis of enzyme extracted from papaya and pineapple skin but there has no work carried out with direct concern of degumming silk by guava leaf. This work mainly focused on degumming efficiency of silk by enzyme extracted from papaya skin, pineapple skin and guava leaf and also focused on different physical properties of silk in conventional and natural degummed method with comparison between them in both methods effect.

\section{Materials and Methods}

\subsection{Material}

In this work, un-degummed spun silk was used, which was collected from Bangladesh Sericulture Research and Training Institute, Rajshahi-6207. Figure and specification of silk fabric is given in Figure 1.

Others necessary chemicals such as Disodium Hydrogen Phosphate $\left(\mathrm{Na}_{2} \mathrm{HPO}_{4}\right)$, Sodium Chloride $(\mathrm{NaCl})$, Sodium Carbonate or Soda $\left(\mathrm{Na}_{2} \mathrm{CO}_{3}\right)$, Hydrogen Peroxide $\left(\mathrm{H}_{2} \mathrm{O}_{2}\right)$, Hydrochloric Acid $(\mathrm{HCl})$ and $1(\%)$ direct red dye which all laboratory grade without any modification were used in this work. 


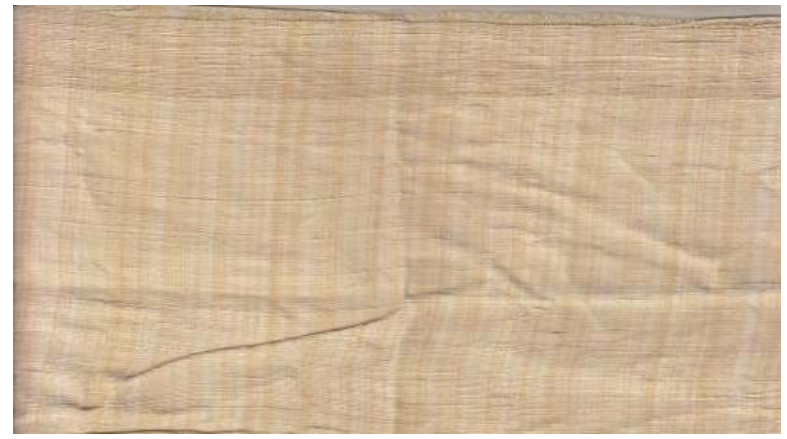

Figure 1. Sample of raw silk $(40 \times 25$ c.m. $)$

\subsection{Enzyme Extraction}

Enzyme is extracted by following [32] with slide change and simply describe here. To 1 liter of Phosphate buffer stock solution, $1.42 \mathrm{gm} \mathrm{Na}_{2} \mathrm{HPO}_{4}$ and $8 \mathrm{gm}$ $\mathrm{NaCl}$ were mixed by the formula of

$$
W=C M V
$$

( $W=$ Mass in gram of solute, $C=$ Concentration of the molecule, $M=$ Mass of the molecule in gram, $V=$ Volume of solution require in liters) with 1-liter distilled water and adjusted the $\mathrm{P}^{\mathrm{H}}$ range 4.5 - 6. Papaya skin, pineapple skin and guava leaf dried by exposure under sunlight until it becomes crunchy and then crush it with mortar-shell and to bring powder form as far as possible. Then mixed these extracted powders at an amount of 10 gm per $100 \mathrm{ml}$ Phosphate buffer and kept in a dark place for 24 hours. Then the solution filtered and finally the enzyme extracted from Papaya skin, pineapple skin and guava leaf.

From Table 1 and Table 2, we can observe that, natural enzymes are used in natural degumming in lieu of soda and detergent which is the unique difference of this manuscript. Also, there is a change in temperature between these two tables.

\subsection{Sample Preparation}

Degummed solutions were prepared by the below-mentioned recipe. Then un-degummed silk sample added in the solution. GyroWash machine was used to degum samples and finally washed and rinsed the sample (See Figure 2).

\subsection{Degumming Efficiency Test}

The degumming efficiency of silk is measured by following formula

$$
\text { Degumming Efficiency }(\%)=\frac{W_{1}-W_{2}}{W_{1}} \times 100
$$

here, $W_{1}=$ Weight before degumming.

$W_{2}=$ Weight after degumming.

Tensile strength, Water vapor permeability, Abrasion, Pilling, and Crease recovery test of fabric is done by ASTM D5034, Cup method, ISO 12947-1, ISO 12945-2, BS 3086 method respectively. 


\begin{tabular}{cc}
\hline Fiber & Mulberry Spun Silk \\
\hline Weave Structure & Plain Weave \\
Ends Per Inch (EPI) & 90 \\
Picks Per Inch (PPI) & 85 \\
Warp count & 60 \\
Weft count & 60 \\
Fabric GSM & 80 \\
Country of origin & Bangladesh \\
\hline
\end{tabular}

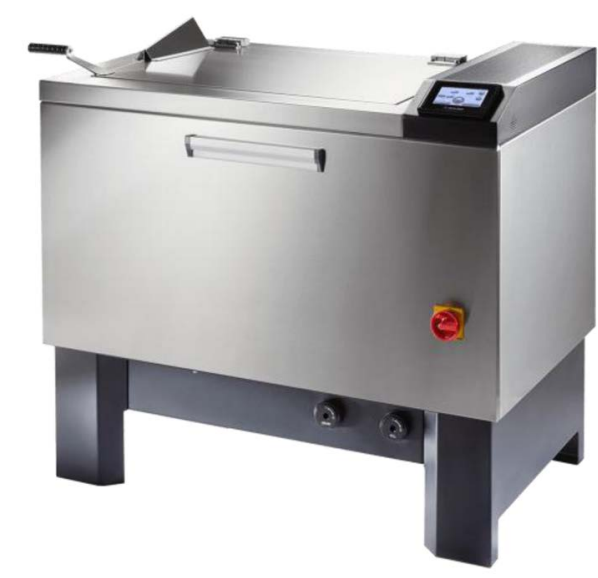

Figure 2. GyroWash Machine (James Heal).

Table 1. Natural degumming recipe of silk.

\begin{tabular}{cc}
\hline Parameter & Quantity \\
\hline Enzyme (\%) & On the amount of liquor $10(\%), 15(\%)$ and $20(\%)$ \\
$\mathrm{H}_{2} \mathrm{O}_{2}$ & $7.5 \mathrm{gm} / \mathrm{L}$ \\
Temperature & $\left(35^{\circ} \mathrm{C}, 45^{\circ} \mathrm{C}\right.$ and $\left.55^{\circ} \mathrm{C}\right)$ \\
Time & 1.5 hour \\
M:L & $1: 20$ \\
Machine & Gyro wash \\
\hline
\end{tabular}

Table 2. Conventional degumming recipe.

\begin{tabular}{cc}
\hline Parameter & Quantity \\
\hline Soda $\left(\mathrm{Na}_{2} \mathrm{CO}_{3}\right)$ & $1 \mathrm{gm} / \mathrm{L}$ \\
Detergent & $0.5 \mathrm{gm} / \mathrm{L}$ \\
$\mathrm{H}_{2} \mathrm{O}_{2}$ & $5 \mathrm{gm} / \mathrm{L}$ \\
Temperature & $80^{\circ} \mathrm{C}$ \\
Time & 1 hour \\
M:L & $1: 20$ \\
Machine & Gyro wash
\end{tabular}




\section{Result \& Discussion}

\subsection{Degumming Efficiency}

In this research degummed the raw silk by "papaya skin, pineapple skin and Guava leaf" enzymes using $10(\%), 15(\%), 20(\%)$ concentration at $35^{\circ} \mathrm{C}, 45^{\circ} \mathrm{C}$ and $55^{\circ} \mathrm{C}$ temperature. Among those temperatures $45^{\circ} \mathrm{C}$ show the best result. So, result of $45^{\circ} \mathrm{C}$ temperature of those samples is given in Figure 3.

From the diagram, degumming efficiency among naturally degummed samples the papaya skin enzyme shows the best result $15.9(\%)$ at 15 (\%) concentration and the conventional method is $16.6(\%)$. There is little difference of degumming efficiency 0.7 (\%) between natural and conventional method. All of the other tests were done on the basis of maximum degumming efficiency i.e. $45^{\circ} \mathrm{C}$ temperature degummed samples.

\subsection{Tensile Strength}

From the lower diagram of Figure 4(a), tensile strength along warp direction among naturally degummed samples the pineapple skin enzyme shows the maximum force $661.4 \mathrm{~N}$ at 10 (\%) concentration and the conventional method is 582.2 N. Again, from the lower diagram of Figure 4(b), tensile strength along weft direction among naturally degummed samples the pineapple skin enzyme also shows the maximum force $566.5 \mathrm{~N}$ at 20 (\%) concentrations and the conventional method is $467.5 \mathrm{~N}$. Tensile strength, both for warp and weft direction of silk fabric degummed by natural enzyme exhibit better result than conventional degumming.

\subsection{Water Vapor Permeability}

From Figure 5, water vapor permeability among naturally degummed samples the Guava leaf enzyme shows the maximum result $1422\left(\mathrm{gm} / \mathrm{m}^{2} /\right.$ day) at $15(\%)$ concentration and the conventional method is $1355\left(\mathrm{gm} / \mathrm{m}^{2} /\right.$ day $)$. Here water vapor permeability of silk fabric degummed by natural enzyme showed better result than conventional degumming.

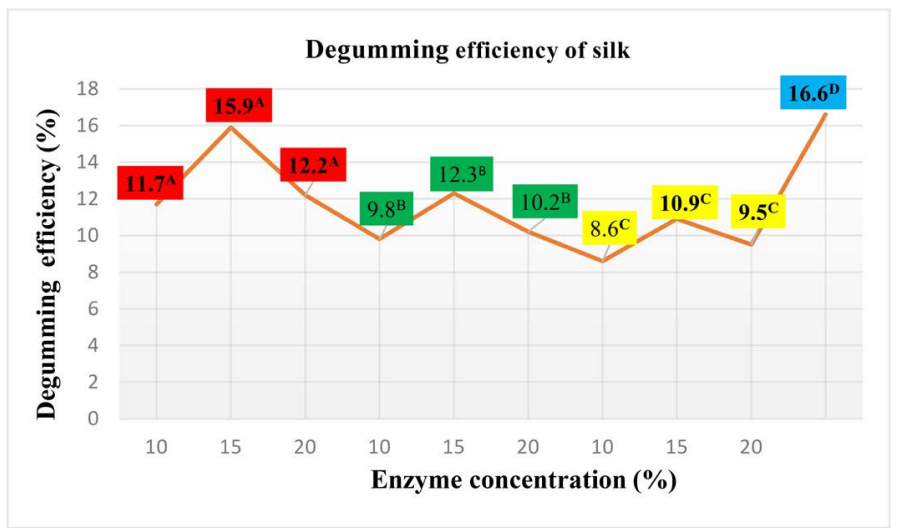

Figure 3. Degumming efficiency of silk by natural and conventional method.

Papaya skin, $\mathrm{B}$ = Pineapple skin, $\mathrm{C}$ = Guava Leaf, $\mathrm{D}=$ Conventional . 
(a) Tensile strength in warp direction

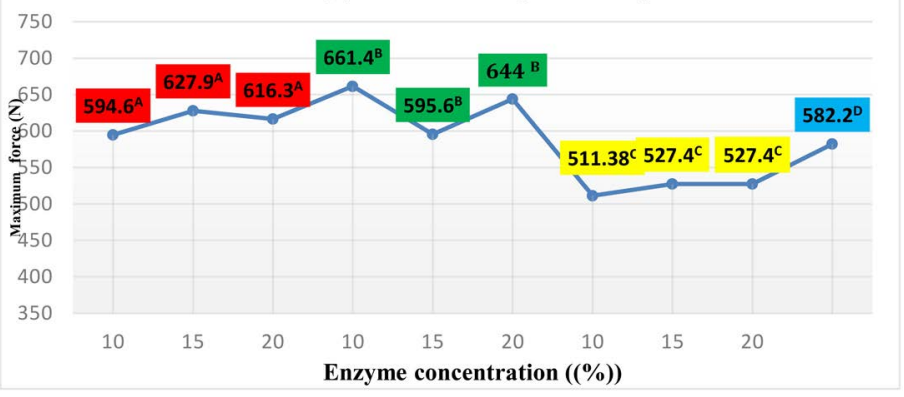

(b) Tensile strength in weft direction

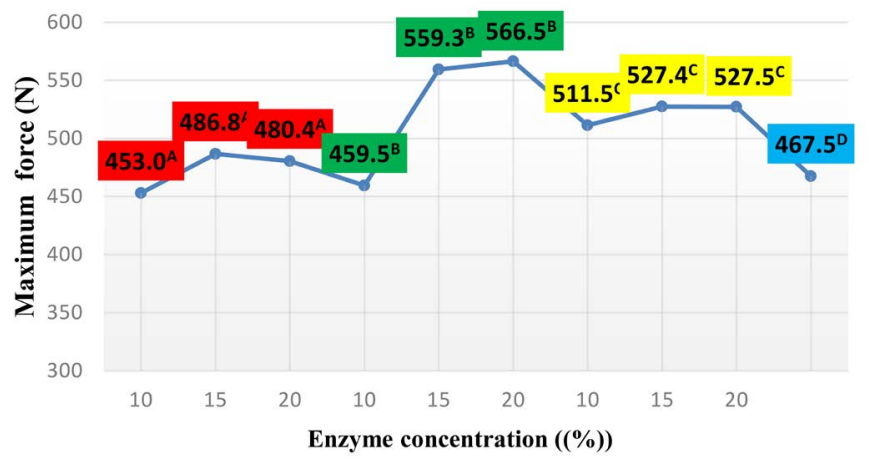

Figure 4. Tensile strength of silk by natural and conventional method, (a) for warp direction and (b) for weft direction of silk fabric. (a) $\mathrm{A}=$ Papaya skin, $\mathrm{B}=$ Pineapple skin, $\mathrm{C}$ = Guava Leaf $\mathrm{D}$ = Conventional. (b) $\mathrm{A}$ = Papaya skin, $\mathrm{B}$ = Pineapple skin, $\mathrm{C}=$ Guava Leaf, $\mathrm{D}=$ Conventional.

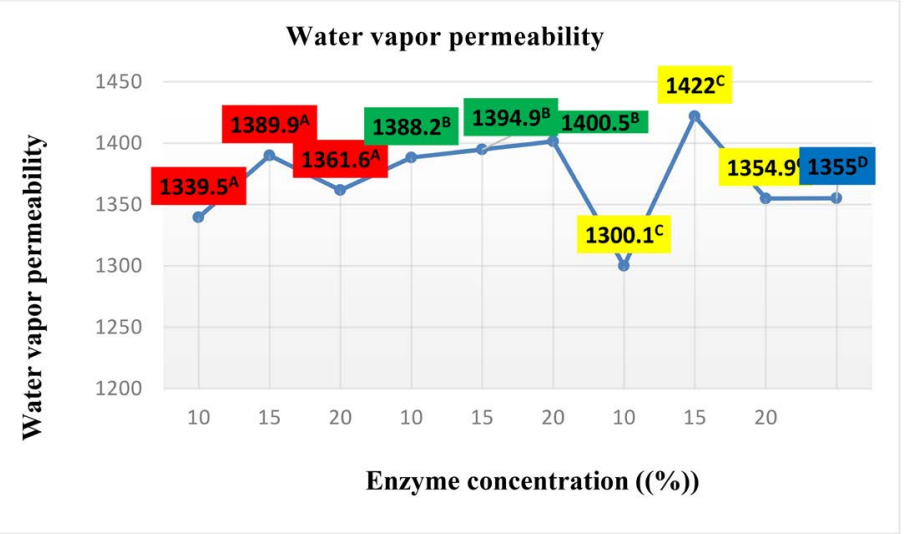

Figure 5. Water vapor permeability of silk by natural and conventional method.

Papaya skin, $\mathrm{B}$ = Pineapple skin, $\mathrm{C}$ = Guava Leaf, $\mathrm{D}=$ Conventional.

\subsection{Whiteness Test}

From Figure 6, whiteness test among degummed samples conventional method shows the maximum reflectance and from the natural method papaya skin enzyme shows the maximum reflectance. 


\subsection{Pilling and Abrasion Test}

From Table 3, pilling and abrasion test were not significant effect among the samples degummed by enzyme extracted from natural sources and also sample degummed by conventional method. All of the results were almost similar.

\subsection{Spot and Crease Recovery Test}

From Table 4, there were not any significant effect of "Spot test" among the samples degummed by enzyme extracted from natural sources and also the sample degummed by conventional method. All of the results were almost similar. In case of crease recovery test, there were not any significant effect among the samples degummed by enzyme extracted from natural sources and also the sample degummed by conventional method.

Table 3. Pilling test and abrasion test result.

\begin{tabular}{|c|c|c|c|c|c|}
\hline \multirow{2}{*}{$\begin{array}{c}\text { Sample } \\
\text { no. }\end{array}$} & \multirow{2}{*}{ Enzyme type } & \multirow{2}{*}{$\begin{array}{c}\text { Concentration } \\
(\%)\end{array}$} & \multirow{2}{*}{$\begin{array}{c}\text { No. of } \\
\text { revolution }\end{array}$} & \multicolumn{2}{|c|}{ Result of pilling and abrasion test } \\
\hline & & & & Grade of pilling & Result of abrasion \\
\hline 1 & Papaya skin & 10 & 5000 & 5 & No thread breakage \\
\hline 2 & Papaya skin & 15 & 5000 & 5 & No thread breakage \\
\hline 3 & Papaya skin & 20 & 5000 & 5 & No thread breakage \\
\hline 4 & Pineapple skin & 10 & 5000 & 4 & No thread breakage \\
\hline 5 & Pineapple skin & 15 & 5000 & 5 & No thread breakage \\
\hline 6 & Pineapple skin & 20 & 5000 & 4 & No thread breakage \\
\hline 7 & Guava leaf & 10 & 5000 & 5 & No thread breakage \\
\hline 8 & Guava leaf & 15 & 5000 & 5 & No thread breakage \\
\hline 9 & Guava leaf & 20 & 5000 & 4 & No thread breakage \\
\hline 10 & conventional & conventional & 5000 & 5 & No thread breakage \\
\hline
\end{tabular}

Table 4. Spot test and Crease recovery test result.

\begin{tabular}{ccccc}
\hline Sample no. & Enzyme type & Concentration (\%) & Condition of spot test & Crease recovery angle $\left(^{\circ}\right)$ \\
\hline 1 & Papaya skin & 10 & Uniform & $57^{\circ}$ \\
2 & Papaya skin & 15 & Uniform & $65^{\circ}$ \\
3 & Papaya skin & 20 & Uniform & $60^{\circ}$ \\
4 & Pineapple skin & 10 & Uneven & $53^{\circ}$ \\
5 & Pineapple skin & 15 & Uniform & $55^{\circ}$ \\
6 & Pineapple skin & 20 & Uniform & $58^{\circ}$ \\
7 & Guava leaf & 10 & Uneven & $62^{\circ}$ \\
8 & Guava leaf & 15 & Uneven & $57^{\circ}$ \\
9 & Guava leaf & 20 & Uneven & $55^{\circ}$ \\
10 & conventional & conventional & Uniform & $61^{\circ}$ \\
\hline
\end{tabular}




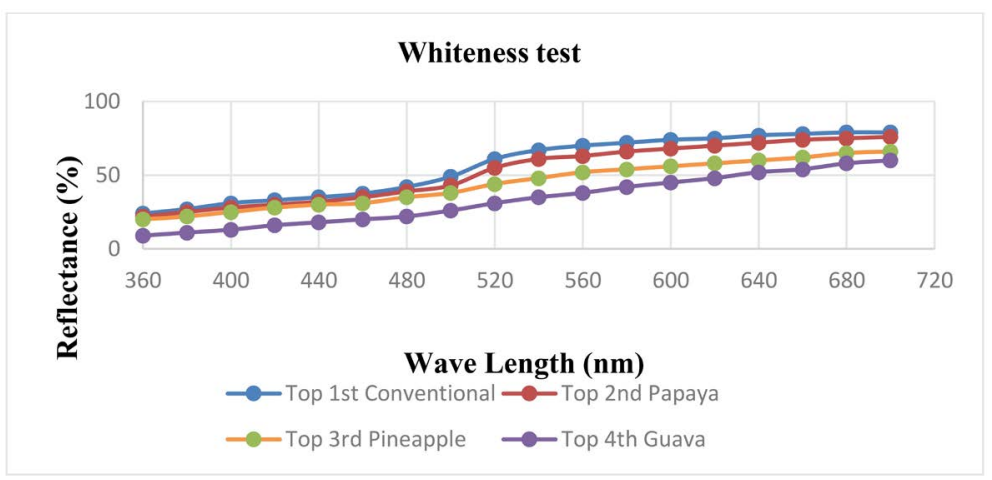

Figure 6. Whiteness test of silk by natural and conventional method.

\section{Conclusion}

Normally silk is popularly degummed by conventional method all over the world. Enzymes are natural products, totally biodegradable and finish their work efficiently without leaving pollutants behind. The enzyme prepared as mentioned way and the samples were degummed in natural and conventional method. In natural degumming this project deals with different natural enzymes extracted from papaya skin, pineapple skin and guava leaf with variation of enzyme concentration $10(\%), 15(\%)$ and $20(\%)$ as well as $35^{\circ} \mathrm{C} 45^{\circ} \mathrm{C}$ and $55^{\circ} \mathrm{C}$ temperature that influences the degumming efficiency. Every sample was degummed at each temperature with each concentration. It was found that, the enzyme extracted from papaya skin shows the best result at 15 (\%) concentration and $45^{\circ} \mathrm{C}$ temperature. On the basis of degumming efficiency other test results were also satisfactory comparing with the conventional method. It is concluded that green degumming can be better than conventional degumming method and this natural method can be altered considering the environmental issue.

\section{Compliance with Ethics Requirements}

This article does not contain any studies with human or animal subjects performed by any of the authors.

\section{Acknowledgements}

The authors gratefully acknowledge Research Cell of Mawlana Bhashani Science and Technology University for financial support of this work.

\section{Conflicts of Interest}

The authors declare no conflicts of interest regarding the publication of this paper.

\section{References}

[1] Altman, G.H., Diaz, F., Jakuba, C., Calabro, T., Horan, R.L., Chen, J., Lu, H., Richmond, J. and Kaplan, D.L. (2003) Silk-Based Biomaterials. Biomaterials, 24, 401-416. https://doi.org/10.1016/S0142-9612(02)00353-8 
[2] Talebpour, F. and Veysian, S.M. (2013) Degumming of Silk Yarn Using Alkali, Enzyme and Seidlitzia rosmarinus. Journal of Textiles and Polymers, 1, 60-64.

[3] Lo, C.H. and Chao, Y. (2017) Degumming of Silk Fibers by $\mathrm{CO}_{2}$ Supercritical Fluid. Journal of Materials Science and Chemical Engineering, 5, 1-8. https://doi.org/10.4236/msce.2017.54001

[4] Chopra, S. and Gulrajani, M.L. (1994) Comparative Evaluation of the Various Methods of Degumming Silk.

[5] Sarker, P., Asif, A.A.H., Rahman, M., Islam, M.M. and Rahman, K.H. (2020) Green Dyeing of Silk Fabric with Turmeric Powder Using Tamarind Seed Coat as Mordant. Journal of Materials Science and Chemical Engineering, 8, 65-80. https://doi.org/10.4236/msce.2020.82007

[6] Ibrahim, N.A., El Hossamy, M., Nessim, A. and Hassan, T.M. (2007) Performance of Bio-Degumming versus Conventional Degumming Processes. Colourage, $54,63-74$

[7] Lewis, R. (1996) Unraveling the Weave of Spider Silk. Bioscience, 46, 636-638. https://doi.org/10.2307/1312891

[8] Sharma, I.C., Chattopadhyay, D.P., Mukhopadhyay, A. and Boruah, R.K. (1999) Effect of Degumming Followed by Sequential Oxidative and Reductive Bleaching on Mulberry and Tasar Silk Fabrics.

[9] Kim, H.J. and Um, I.C. (2013) Effect of Processing Conditions on the Homogeneity of Partially Degummed Silk Evaluated by FTIR Spectroscopy. International Journal of Industrial Entomology, 26, 53-59. https://doi.org/10.7852/ijie.2013.26.1.054

[10] Mahmoodi, N.M., Moghimi, F., Arami, M. and Mazaheri, F. (2010) Silk Degumming Using Microwave Irradiation as an Environmentally Friendly Surface Modification Method. Fibers and Polymers, 11, 234-240. https://doi.org/10.1007/s12221-010-0234-2

[11] Rodbumrer, P., Arthan, D., Uyen, U., Yuvaniyama, J., Svasti, J. and Wongsaengchantra, P.Y. (2012) Functional Expression of a Bombyx mori Cocoonase: Potential Application for Silk Degumming. Acta Biochimica et Biophysica Sinica, 44, 974-983. https://doi.org/10.1093/abbs/gms090

[12] Sonjui, T., Noomhorm, C. and Promboon, A. (2009) Sericin Recovery from Silk Cocoon Degumming Wastewater by Membrane Process. Doctoral Dissertation, Kasetsart University, Bangkok.

[13] Sumana, D., Sudarshan, M., Thakur, A.R. and RayChaudhuri, S. (2013) Degumming of Raw Silk Fabric with Help of Marine Extracellular Protease. American Journal of Biochemistry \& Biotechnology, 9, 12. https://doi.org/10.3844/ajbbsp.2013.12.18

[14] Luong, T.H., Dang, T.N.N., Ngoc, O.P.T., Dinh-Thuy, T.H., Nguyen, T.H., Van Toi, V., Duong, H.T. and Le Son, H. (2015) Investigation of the Silk Fiber Extraction Process from the Vietnam Natural Bombyx Mori Silkworm Cocoon. In: 5th International Conference on Biomedical Engineering in Vietnam, Springer, Cham, 325-328. https://doi.org/10.1007/978-3-319-11776-8 79

[15] Gulrajani, M.L., Agarwal, R., Grover, A. and Suri, M. (2000) Degumming of Silk with Lipase and Protease.

[16] Pervin, A.N.İ.Ş., Çapar, G., Toprak, T. and Yener, E. (2016) Sericin Removal from Silk Fibers with Eco-Friendly Alternative Methods. Tekstil ve Konfeksiyon, 26, 368-374.

[17] Gulrajani, M.L. (1992) Degumming of Silk. Review of Progress in Coloration and 
Related Topics, 22, 79-89. https://doi.org/10.1111/j.1478-4408.1992.tb00091.x

[18] Sasithorn, N. and Luepong, K. (2009) Silk Degumming with Dried Latex of Carica papaya Linn.

[19] Anghileri, A., Freddi, G., Mossotti, R. and Innocenti, R. (2007) Mechanical Properties of Silk Yarn Degummed with Several Proteases. Journal of Natural Fibers, 4, 13-23. https://doi.org/10.1300/J395v04n01 02

[20] Park, G.Y. and Kim, H.C. (2017) Research on Degumming and Fixing Sericin to Obtain Sericin-Fixed Souple Silk Yarns without Formaldehyde. Journal of Engineered Fibers and Fabrics, 12. https://doi.org/10.1177/155892501701200407

[21] Arami, M., Rahimi, S., Mivehie, L., Mazaheri, F. and Mahmoodi, N.M. (2007) Degumming of Persian Silk with Mixed Proteolytic Enzymes. Journal of Applied Polymer Science, 106, 267-275. https://doi.org/10.1002/app.26492

[22] Wainaina, W.P. (2011) Effect of Pineapple (Ananas comosus L. Merrill) and Papaya (Carica papaya L.) Fruit Extracts on Sericin Removal from Silk Moths' Cocoons in Kenya. Doctoral Dissertation.

[23] Ninpetch, U., Tsukada, M. and Promboon, A. (2015) Mechanical Properties of Silk Fabric Degummed with Bromelain. Journal of Engineered Fabrics \& Fibers (JEFF), 10, 69-78. https://doi.org/10.1177/155892501501000319

[24] Koh, L.D., Cheng, Y., Teng, C.P., Khin, Y.W., Loh, X.J., Tee, S.Y., Low, M., Ye, E., Yu, H.D., Zhang, Y.W. and Han, M.Y. (2015) Structures, Mechanical Properties and Applications of Silk Fibroin Materials. Progress in Polymer Science, 46, 86-110. https://doi.org/10.1016/j.progpolymsci.2015.02.001

[25] Li, G., Liu, H., Zhao, H., Gao, Y., Wang, J., Jiang, H. and Boughton, R.I. (2011) Chemical Assembly of $\mathrm{TiO}_{2}$ and $\mathrm{TiO}_{2} @$ Ag Nanoparticles on Silk Fiber to Produce Multifunctional Fabrics. Journal of Colloid and Interface Science, 358, 307-315. https://doi.org/10.1016/j.jcis.2011.02.053

[26] Lu, Y.H., Lin, H., Chen, Y.Y., Wang, C. and Hua, Y.R. (2007) Structure and Performance of Bombyx mori Silk Modified with $\mathrm{Nano}^{-\mathrm{TiO}_{2}}$ and Chitosan. Fibers and Polymers, 8, 1-6. https://doi.org/10.1007/BF02908152

[27] Gupta, M.K., Khokhar, S.K., Phillips, D.M., Sowards, L.A., Drummy, L.F., Kadakia, M.P. and Naik, R.R. (2007) Patterned Silk Films Cast from Ionic Liquid Solubilized Fibroin as Scaffolds for Cell Growth. Langmuir, 23, 1315-1319. https://doi.org/10.1021/la062047p

[28] Ayatullah Hosne Asif, A.K.M., Rahman, M., Sarker, P., Ha-san, Md.Z. and Paul, D. (2019) Hydrogel Fibre: Future Material of Interest for Bio-Medical Applications. Journal of Textile Science and Technology, 5, 92-107.

https://doi.org/10.4236/jtst.2019.54009

[29] Kundu, J., Patra, C. and Kundu, S.C. (2008) Design, Fabrication and Characterization of Silk Fibroin-HPMC-PEG Blended Films as Vehicle for Transmucosal Delivery. Materials Science and Engineering: C, 28, 1376-1380. https://doi.org/10.1016/j.msec.2008.03.004

[30] Masini, B.D., Stinner, D.J., Waterman, S.M. and Wenke, J.C. (2011) Bacterial Adherence to High-Tensile Strength Sutures. Arthroscopy: The Journal of Arthroscopic \& Related Surgery, 27, 834-838. https://doi.org/10.1016/j.arthro.2011.02.003

[31] Antony, V.R. and Chinnammal, S.K. (2013) Degumming of Silk Using Papaya Skin. Journal of Environmental Nanotechnology, 2, 10-16. https://doi.org/10.13074/jent.2013.09.132024

[32] Manosroi, A., Chankhampan, C., Pattamapun, K., Manosroi, W. and Manosroi, J. 
(2014) Antioxidant and Gelatinolytic Activities of Papain from Papaya Latex and Bromelain from Pineapple Fruits. Chiang Mai Journal of Science, 41, 635-648.

[33] Nakpathom, M., Somboon, B. and Narumol, N. (2009) Papain Enzymatic Degumming of Thai Bombyx mori Silk Fibers. Journal of Microscopy Society of Thailand, 23, 142-146. 